\title{
Katarzyna Trzeciak \\ Posągi jako źródła nowej epistemologii (przypadek Michela Serresa)
}

\begin{abstract}
Trzeciak Katarzyna, Posągi jako źródła nowej epistemologii (przypadek Michela Serresa) [Statues as a source of new epistemology (the case of Michel Serres)]. „Przestrzenie Teorii" 27. Poznań 2017, Adam Mickiewicz University Press, pp. 245-258. ISSN 1644-6763. DOI 10.14746/pt.2017.27.17.

The article attempts to read the metaphor of the statue in Michel Serres' philosophical discourse. Sculpture understood in the broad sense, as Serres proposes in Statues: The Second Book of Foundations, enables him to trace a whole array of concepts in western thought, and to make the statue itself a model of new cognition, extending beyond binary oppositions and open to unpredictability and a lack of continuity. For Serres a statue also offers the possibility to cross the boundaries of science and the humanities, and consequently to become, at the same time, both a critical and utopian figure.
\end{abstract}

Rzeźba: ucieleśnienie prawdy Bycia w jej fundującym miejsca dziele

Martin Heidegger, Sztuka i przestrzeń

Stawką całego filozoficznego projektu Michela Serresa jest przemyślenie zachodniej epistemologii poprzez przekroczenie przepaści między naukami ścisłymi i humanistycznymi. Jego wysiłek intelektualny nastawiony jest na poszukiwanie nowej ekspresji naukowej, w ramach której pojęcia matematyczne mogą współdziałać z językiem poetyckim nie jako antagonistyczne, lecz jako wzajemnie dopełniające się sposoby ujmowania rzeczywistości ${ }^{1}$.

Ośrodkiem tego osobliwego, nierzadko problematycznego współdziałania jest w dyskursie Serresa zawsze inna metafora - „piękna mącicielka” (la belle noiseuse), która za każdym razem służy jako zwornik wieloznaczności i nieokreślony fundament nowego sposobu myślenia o kluczowych kategoriach determinujących poznanie. Wśród tych metafor znajdziemy figurę mitycznego Hermesa, a także pojęcia „pasożyta”, których znaczenia są aktualizowane $\mathrm{w}$ oparciu o ich epistemologiczne pod-

1 Do tej krótkiej, syntetycznej charakterystyki nawiązują badacze podejmujący wysiłek przybliżania skomplikowanego dyskursu francuskiego filozofa - zob. M.L. Asad, Portrait of a Nonlinear Dynamical System: The Discourse of Michel Serres, „SubStance” 1993, Vol. 22, No. 2/3, Issue 71/72: Special Issue: Epistémocritique, s. 141, <http://www.jstor.org/ stable/3685276> (dostęp: 28.05.2017). 
stawy - na przykład mitologię czy etymologię i rozszerzane tak, by wyzyskać ich wieloznaczność, maskowaną w toku racjonalizujących praktyk logocentrycznego myślenia.

W niniejszym szkicu zwracam uwagę na metaforyczną obecność pojęcia o szczególnie rozległym znaczeniu - posąg to bowiem dla Serresa figura źródłowa, otwierająca możliwość przedefiniowania samej źródłowości, jak też inicjująca nowy model wiedzy, jednocześnie scentralizowany, ale i dynamicznie płynny, wymuszajacy otwarcie się na to, co niezorganizowane, nieprzewidywalne i zagrażające wszelkim formom stabilnego kategoryzowania.

W jaki sposób jednakże posąg, intuicyjnie przywołujący na myśl raczej formy zamknięte, stabilne i nieruchome, może stać się figurą zmienności i nieprzewidywalności? Przede wszystkim potrzebne jest „odciążenie” go od tyranii bryły i statyczności, a także zgoda na rezygnację z opozycyjnego ujmowania nieruchomości i zmienności.

\section{Dryfujące szczątki}

Przez iluminatory widać było smętne widmo psa oraz różne inne przedmioty wyrzucone w swoim czasie z pocisku, które uparcie towarzyszyły mu w drodze. Spoglądając na szczątki Satelity, Diana wyła żałośnie. Wydawały się tak nieruchome, jak gdyby spoczywały na twardym gruncie.

- Wiecie, przyjaciele - rzekł Michał Ardan - że gdyby któryś z nas nie wytrzymał przeciwuderzenia przy odlocie, mielibyśmy ogromny kłopot z pochowaniem go, a raczej z „eterowaniem”, skoro eter zastępuje tu ziemię. Wyobrażacie sobie takiego truposza, który jak wyrzut sumienia towarzyszyłby nam nieustannie?2.

To fragment powieści Wokót Księżyca, drugiej części trylogii Jules’a Verne’a Z Ziemi na Księżyc, dotyczący osobliwej obserwacji, która staje się udziałem grupy podróżujących na Księżyc astronautów. „Widmo psa” to po prostu wyrzucony wcześniej ze statku, zamarznięty pies, Satelita, którego bohaterowie musieli pozbyć się, by zachować higienę miejsca, w którym się znajdują. Dryfujące w przestrzeni szczątki zamarzniętego zwierzęcia są nieruchomym przedmiotem usuniętym $\mathrm{z}$ przestrzeni żywych, który jednakże powraca do nich i staje się obiektem spojrzenia przypominającym posąg. Dla Serresa, autora Statues: Le second livre des fondations $(1987)^{3}$, obserwacja tego szczególnego obiektu w po-

2 J. Verne, Wokót księżyca, przeł. L. Duninowska, Warszawa 1970, s. 205.

3 „Druga księga źródeł” odnosi się do całej trylogii Serresa: pierwsza książka z cyklu to Rome: le livre des fondations (1983), trzecia - Les origines de la géometrie (1993). Trylogia francuskiego filozofa dotyczy źródeł zachodniej kultury i w każdej z nich Serres, za 
wieści Verne’a jest zwornikiem myślenia o posągach jako figurze epistemicznej4.

W wielu miejscach refleksji Serresa posąg ${ }^{5}$ (statua) traktowany jest zgodnie z łacińską etymologią stare - „stać” w opozycji do tego, co płynne, zmienne, nieuporządkowane. Serres sięgał po figurę posągu, by metonimicznie określić porządek statyczności i tyranii racjonalnego działania. „Bezruch, stałość, teza” to warunki każdego systemu opartego na binarnych opozycjach i zasadzie tożsamości6.

Potępiając racjonalizm za tyranię zaszczepiania się na każdej myśli i intelektualnej twórczości, Serres [...] traktuje posąg jako prawdziwy fetysz, symptomatyczny dla narastającego pragnienia rozumu, by zarządzać światem empirycznym i przeobrażać go w zbiór spornych obiektów. We wcześniejszych tekstach, Hermes i pasożyt funkcjonują jako figury weryfikujące, podważające niepodzielną władzę porządku i stagnacji ${ }^{7}$.

W Statues Serres sięga po posągopodobne ciało psa z powieści Verne'a, by sprowokować inny rodzaj myślenia o posągu, a w konsekwencji także o strukturze poznania i modelu podmiotowej egzystencji w relacji do świata przedmiotów. Innymi słowy - odkrywa, że w ramach interesującego go od zawsze systemu, zbudowanego na założeniu o podmiocie docierającym do poznania rzeczy (świata), pojawia się trzeci element, zapośredniczający binarną opozycję. Wyrzucony ze statku kosmicznego trup powoduje, że system podmiotowo-przedmiotowy zostaje wytrącony z porządku. Dryfujący w przestrzeni trup przyłącza się do systemu żywych i na chwilę całkowicie przykuwa ich uwagę. Zafascynowany nieplanowa-

pomocą różnych, nierzadko odległych od siebie figur, stawia pytania o kluczowe kategorie poznawcze i ontologiczne fundamenty metafizyki. W Rzymie zajmują go kwestie początków społeczeństwa, wiedzy, kultury, a główne miasto cywilizacji Zachodu dostarcza mu narzędzi pojęciowych do śledzenia relacji pomiędzy naukami ścisłymi a estetyką. W trzeciej części, Geometrii, sięga natomiast do Grecji i narodzin geometrii, co daje mu podstawę do rozbudowanego śledztwa źródeł mechanicystycznej nowoczesności.

${ }_{4}$ M. Serres, Statues: The Second Book of Foundations, przeł. R. Burks, London-New Delhi-New York-Sydney 2015. Wszystkie cytaty pochodzące z tego wydania zaznaczam w tekście głównym podaniem numeru strony w nawiasie kwadratowym. Wszystkie tłumaczenia, jeśli nie podano inaczej, pochodzą ode mnie.

${ }^{5}$ Mówiąc o posągu, Serres postępuje przeciwko podziałom na rzeźbę, pomnik czy inne rzeźbiarskie formy. Posągiem jest dla niego zarówno zmumifikowane ciało, jak i kawałek kamienia, przez co jego rozważania nie respektują tradycyjnych podziałów artystycznych (jak choćby Herdera, precyzyjnie wyszczególniającego, czym jest rzeźba i co różni ją od innych form sztuki przestrzennej - J.G. Herder, Sculpture: Some Observations on Shape and Form from Pygmalion's Creative Dream, przeł. J. Gaiger, Chicago, London 2002, s. 9).

${ }_{6}$ M. Serres, Le cinq sens, Paris: Grasset, 1985, cyt. za: M.L. Assad, Reading with Michel Serres: An Encounter with Time, New York 1999, s. 109.

7 Tamże. 
nym widokiem podmiot porzuca pierwotny cel, czyli obserwację gwiazd, widząc przed sobą wyłącznie widmowy posąg śmierci.

W warunkach ziemskich, wskazuje Serres, pośmiertne resztki są wchłaniane i znikają bezpowrotnie. Ziemia daje i odbiera, utrzymując równowagę porządków. „Dzięki temu, zwykliśmy sądzić, że nic się nie stało" [S 18]. Taki sąd inicjuje pracę zapomnienia, które wspiera i napędza ślepo racjonalizujący pociąg do linearności myślenia, w którym, to, co stabilne, ucieleśnione w posągu, daje gwarancję porządku następujacych po sobie etapów. Kiedy jednak - jak w powieści Verne'a - brakuje Ziemi, harmonia zostaje zaburzona - nic nie zostało stworzone ani stracone, wszystko podlega wyłącznie nieustannym przeobrażeniom. I wówczas

racjonalność przywraca równowagę, porządek i proporcje: taka jest jej właściwa definicja, od słowa, z którego pochodzi [...]. I dlatego racjonalność będzie zawsze przywracać rzecz wyrzuconą, inaczej niż Ziemia, która utrzymuje, ukrywa, rozpuszcza i anihiluje. Trup powróci, jeśli wrzucisz go w pustkę; rozum przyniesie go z powrotem, lecz nigdy nie powróci z ziemskiej głębi, w którą zacznie wzrastać niepostrzeżenie. Rozum rozpoznaje się poprzez jego widma. [S 18]

Dlatego Serres może powiedzieć, że relacja podmiotu i przedmiotu jest stabilizowana przez śmierć i jako taka, trójelementowa, definiuje status posąu, „twardego niczym przedmiot, ciała zmarłego, zakonserwowanego lub przywróconego" [S 19].

Posąg w skomplikowanym dyskursie Serresa staje się modelem nowej wiedzy, w którym wiąże ona podmiot z przedmiotem w niezbywalnej asyście śmierci, zapośredniczającej relację. Dzięki takiemu zapośredniczeniu to posąg właśnie staje się warunkiem możliwości poznania. Jest to możliwe, bowiem francuski autor uznaje posąg za kulturową figurę, która zdradza i zaburza znany nam system znaczenia. Przedmiot z kamienia staje się posągiem-pomnikiem umieszczonym na miejscu pochówku, by podtrzymywać pamięć o zmarłym, anihilowanym przez śmierć. Tak rozumiany posąg-pomnik ma strukturę widmową, podobną do wyrzuconego ze statku ciała psa, przywróconego przez rozum, który jest pewien, że w pustce nic nie może zostać wchłonięte. Serres, choć nie podsuwa jednoznacznego ujęcia posągu, zdaje się czerpać przede wszystkim z jego metonimicznego statusu, jako czegoś, co zastępuje zmarłe ciało i nie pozwala mu odejść, służąc żywym ze zwornik pamięci i trwania w czasie. Autor przypomina, że archaiczny posąg to antropomorficzna stela - reprezentacja kogoś, kto leży pod wzniesionym obiektem. Pomnik ukrywa to znajdujące się pod nim wnętrze - trup, mumia leżą tam, gdzie wznosi się posąg. A jednocześnie pomnik prowadzi do usunięcia biologicznej śmierci, oswojenia jej w relacji zapośredniczenia („Co to jest posąg? To żywe ciało 
przykryte kamieniami” [S 181]). Dotarcie do wnętrza pomnika i odkrycie jego tajemnicy jest jednak niemożliwe, bo każdy akt drążenia, przedostania się do środka i poznania go pozwala dotrzeć wyłącznie do „dwóch zewnętrznych ścian” [S 58]. A wówczas cała praca musi być wykonywana od początku i bez końca.

\section{Drugie źródło}

W esejach z tomu Statues Serres zestawia pozornie odległe posągi kultową figurę Baala $\mathrm{z}$ amerykańskim Challengerem, by w efekcie takich nieoczywistych zestawień sprowokować dyskusję o kryzysie nowoczesnej epistemologii. Konstruowana przez mitologie, tradycje i religie historia człowieka jest opowieścią o odsunięciu biologicznej śmierci i związanym z tym osiągnięciem „zbiorowej nieśmiertelności”.

Trup szybko staje się tym, co nie posiada imienia w żadnym języku: nie przedstawia go tekst ani obraz. Grupa wyklucza martwego psa, zanim stanie się niewypowiadalny; nie widzi go, nie mówi o nim. Lecz widzi go znowu, gdy powraca jako wysuszona mumia, zakonserwowana w próżni [...]. Grupa znów mówi o nim, o posągu, jako zjawie. [S 24]

Posąg jest dla Serresa tym, co poprzedza język, dlatego „drugie źródło" (podtytuł jednego z esejów) sięga głębiej, do momentu, zanim pojawi się logos. „Posągi przychodzą przed językiem i produkują gatunek ludzki zanim jeszcze język go odnajdzie" [S 23]. Posąg, który ukrywa, a jednocześnie nieustannie przywraca, jest więc poza binarną strukturą, która warunkuje język i znaczenie. „Jego moc referencji to siła znaczenia faktu przemijania, które jest utrwalaniem"8. Według Roberta Harrisona nie jest przypadkiem, że greckie słowo sema (znak) oznacza także grób, bo „dla Greków grób nie był wyłącznie jednym z wielu znaków, ale znakiem źródłowym znaczenia, stoi zamiast tego, co stoi w nim”. Sformułowanie „tu spoczywa...” byłoby więc odniesieniem do zniknięcia, które umożliwia znaczenie i wskazuje na autoreferencjalność. „Z posągów powstają słowa, modlitwy" [S 68].

Rozważania Serresa o posągach w związku z przemianą myślenia o poznaniu krążą wokół pojęcia substytucji: statua zastępuje martwe ciało. „Ty jesteś Piotr [czyli Skała] i na tej Skale zbuduję mój Kościół”10 to fundamentalne zdanie jest dla Serresa znakiem kluczowej transforma-

8 R.P. Harrison, The Dominion of the Dead, Chicago-London 2003, s. 20.

9 Tamże, s. 21.

10 Mt 16,18, Pismo Święte Starego i Nowego Testamentu w przekładzie z języków oryginalnych, Poznań 1998 <http://biblia.deon.pl/rozdzial.php?id=259> (dostęp: 25.06.2017). 
cji żywego ciała w kamienny budulec, w znak, który uruchamia ciąg substytucji. Serres wskazuje, że filozofia, interpretując słowa Pisma, mówi o posągach, bo przywołuje podstawę, fundament i ostateczną stabilność. Jednakże - to najważniejszy chyba zarzut autora - to fundujące zdanie opisuje przeistoczenie żywego ciała w obojętny kamień; ciała w imię; jednostki w instytucję. „Co, naprawdę, pozostaje stabilne w tym łańcuchu substytucji, jeśli nie sama skała, zawsze niezmienna i powracająca w słowie, imieniu, ciele, rzeczy, konstrukcji i montażu?" [S 175].

W micie o Syzyfie również interesuje Serresa nie bohater, wina czy mordercza praca (tak zorientowane interpretacje pozwalają dostrzegać wyłącznie interpretatorów - ludzi dyskutujących o winie i karze), lecz to, co trwa uparcie w tekście mitu - nieustanny upadek skały. To zapomnienie materii jest metaforą zapomnienia w ogóle (jak ziemskie zapomnienie, z którym mierzy się martwy pies z powieści Verne’a), a przywrócenie pamięci to zwrot ku skale - materii, która powraca jako najbardziej niezmienny element opowieści: „Poruszeni historią Syzyfa, utraciliśmy pamięć o kamieniu; zapomnieliśmy, że to nasza odwieczna przeszłość i całkowita przyszłość. Kamienie szkieletów są zarazem zalążkami przyszłości” [S 174].

Powracający w Statues posąg nie może być uznany za coś jednoznacznie stabilnego, nie jest jednakże tylko tym, co nieustannie zmienne. Podążając za zdarzeniami z różnych porządków - tragedią promu kosmicznego Challenger, mumifikacją faraonów, petryfikacją żony Lota - Serres konstruuje posąg jako obiekt zmienny w czasie, dynamiczny, zależny i zarazem warunkujący struktury epistemiczne epoki. Syzyf ucieleśnia relację zarysowaną wcześniej w rozważaniach o statusie posągopodobnego ciała psa - to kombinacja podmiotu, przedmiotu i śmierci, którą Serres wpisuje w ahistoryczny porządek, jednocześnie nie zapominając o odniesieniu do czasowości tej relacji. Daremny trud Syzyfa, nieskończony, a przez to każący myśleć o czasie jako czymś bezsensownym, ujawnia w lekturze Serresa swój pozytywny aspekt: to lekcja „zbiorowej, ahistorycznej nieśmiertelności"11, której figurą jest posąg, nieodłączny element podmiotowo-przedmiotowej relacji. Posąg przywołuje śmierć, lecz po to, by ją zapośredniczyć, ustanowić nielinearny porządek nieśmiertelności.

\section{Posąg jako dziwny atraktor}

Zgodnie z syzyfową zasadą powrotu, w eseju o mitycznym bohaterze Serres powraca do swoich wcześniejszych koncepcji, związanych z posągami. W zbiorze Hermès I Molierowski posąg Komandora był granitową,

11 M.L. Assad, Reading with Michel Serres..., s. 123. 
masywną bryłą, która swą masywnością wprowadza zagrożenie zastoju i śmierci12. W Statues Serres wyznaje

Ta nieustannie ponawiana praca, w której pojawia się niezmienność, pozwala wreszcie, w tym miejscu, zaznaczyć trajektorię kamienia, której nie sporządził nikt wcześniej. U podstaw wzgórza, miejsca łapania oddechu, nabierania powietrza, rozpościera się dno grobu; na szczycie wzgórza, na który znów wtaczana jest skała, gdzie kończy się wysiłek, otwiera się zapadnia. Historia ulega powtórzeniu; wyrasta z podziemi, ze świata zmarłych, z wysuszonych kości przodków. $\mathrm{Tu}$ się zaczyna i tu nieustannie spada. Ale czasem wznosi się ponad ziemię jako menhir, meteor, cippus, pomnik, wieża, obiecujące ukształtowanie, ostateczne wyciosanie i cudowny - dynamiczny... wylot ku niebu. Posągi wspinają się, lecz przede wszystkim, upadają znów w to samo miejsce, zaczynają wzrost od początku [...]. Ostatecznie, wszystkie rzeczy spadają na dno przepaści tych problemów, które wydawały się już przezwyciężone. [S 177-178]

Logika Serresa, której centralnym zwornikiem jest posąg, odsłania w tym fragmencie jego epistemiczno-krytyczny model, przenikający wszystkie eseje Statues. Dla tej logiki Serres uruchamia własną wersję matematycznego pojęcia „dziwnego atraktora”, determinującego chao_tyczność układu dynamicznego. Dziwny atraktor ustanawia globalne ograniczenia zakresu ruchu, lecz w ramach tych ograniczeń nie pozwala przewidzieć dokładnie, jakie zmiany dane trajektorie spowodują na poziomie lokalnym. Przenosząc te ustalenia na myślenie o rozwoju dziejów, Maria L. Assad wskazuje, że globalna przyszłość ma zdefiniowane struktury, oparte na przewidywanych ewolucyjnie wzorach, w których pojawiają się lokalne, pojedyncze punkty zamazanych granic ${ }^{13}$. Historie narosłe wokół opisywanych przez Serresa posągów są momentami takiej konfuzji w samym środku wiedzy jako systematycznej kumulacji znaczeń; otwierają pole wiedzy na nieprzewidywalność.

Rzeźbiarskość przesiedla masę - obcą, nieustannie powracającą, poprzez jednoczenie jej, indywidualizowanie, lokalizowanie w przestrzeni jej znaczenia; stabilizuje niczym martwe ciało, które zatrzymuje czas [...]. Ręce rzeźbiarzy dotykają tego, co nie jest znakiem, ale co gwarantuje, że istniejąca rzecz jest w przestrzeni i nie troszczy się o znaki i znaczenia - tego, co radykalnie obce naszym schematyzacjom. [S 52]

Różne posągi, których posągowość wydaje się na pierwszy rzut oka niemożliwa (jak prom kosmiczny), mają wskazać, że w uniwersalnym statusie wiedzy doszło do zapomnienia jej źródeł, których obcość, nieznajomość budzi lęk, jak lęk budzą posągopodobne ciała złożone w miejskich

12 M. Serres, The Apparition of Hermes: Dom Juan, [w:] tegoż, Hermes: Literature, Science, Philosophy, ed. J.V. Harari, D.F. Bell, Baltimore, London 1982, s. 3-15.

13 M.L. Assad, Reading with Michel Serres..., s. 118. 
kryptach - fundamentach cywilizacji. Snując odległe paralele, Serres powraca nieustannie do rozpoznania o przedjęzykowym statusie posągów, które poprzez swoje milczenie pozostają poza historią logosu, uzurpującego sobie miejsce pierwszeństwa. „Nie znajdziesz w historii czy tradycji żadnej filozoficznej rozprawy naukowej o rzeźbie czy posągu. Język nie mówi o milczeniu" [S 198]14.

Celem Serresa jest wskazanie, że praca przypominania posągów możliwa stała się dzięki rozwojowi myśli matematycznej, między innymi za sprawą ustanowienia pojęcia „dziwnego atraktora”, który nie tyle działa na rzecz poszerzenia pola wiedzy, co zwraca uwagą na momenty nieprzewidywalności. Jednocześnie, konstruując ahistoryczną, nielinearną opowieść o posągach, Serres unaocznia, że historia konstrukcji epistemicznych zawsze zawierała i zawiera punkty „innej wiedzy”, opierającej się wyjaśnieniu w perspektywie przyczynowo-skutkowej. Posągi są takimi punktami, zarówno jako rzeźbione obiekty religijne, zmumifikowane ciała, rzeźby Rodina czy promy kosmiczne. Te punkty „innej wiedzy” nie mają nic wspólnego ze stagnacją i zatrzymaniem intuicyjnie projektowanymi na posąg. Dla Serresa wszystkie je cechuje wewnętrzna dynamika (dlatego może twierdzić, że wzbudzają lęk) - „mogą kruszyć, zagrażać, komplikować [...] zagrażają eksplozją i eksplodują" [S 59]. Celem Statues jest rejestracja takich niemych eksplozji, które przydarzają się posągom i konstytuują „drugie źródło”. To źródło pozwala rozpoznać aktywność rozumu, który przywraca swoje widma (posągowe), by utrzymać racjonalność w samym środku niepewności, nieprzewidywalności. Historia nauki i technologii musi wspierać się na punktach „innej wiedzy”, które ją warunkują. Posągi są dla Serresa takim szczególnym punktem wsparcia, który pozwala przeformułować strategie poznania poprzez zakwestionowanie stabilności fundamentów tegoż poznania, a w konsekwencji przez uznanie ich za źródło nielinearnego, dynamicznego systemu poznania.

\title{
Monumentalność w głębi czasu
}

\author{
Posągi stoją w głębi czasu, \\ W przejrzystej wodzie głębinowej: \\ Twarze obmyte $\mathrm{z}$ rysów,
}

${ }^{14} \mathrm{Z}$ innej perspektywy o milczeniu dzieła sztuki mówił Derrida, wskazując na jego dwie możliwe interpretacje: kompletne milczenie, w którym słowa osiągają swój limit, oraz fakt, że milczenie dzieła wymusza „dyskursywną wirtualność” odbiorcy, jego projekcje, które mogą wymknąć się hegemonii dyskursu za sprawą aktywności odbiorcy, nastawionej na nieustanne relatywizowanie komunikatu, płynącego z przestrzennego dzieła sztuki zob. E. Bilman, Modern Ekphrasis, Bern 2013, s. 133. 


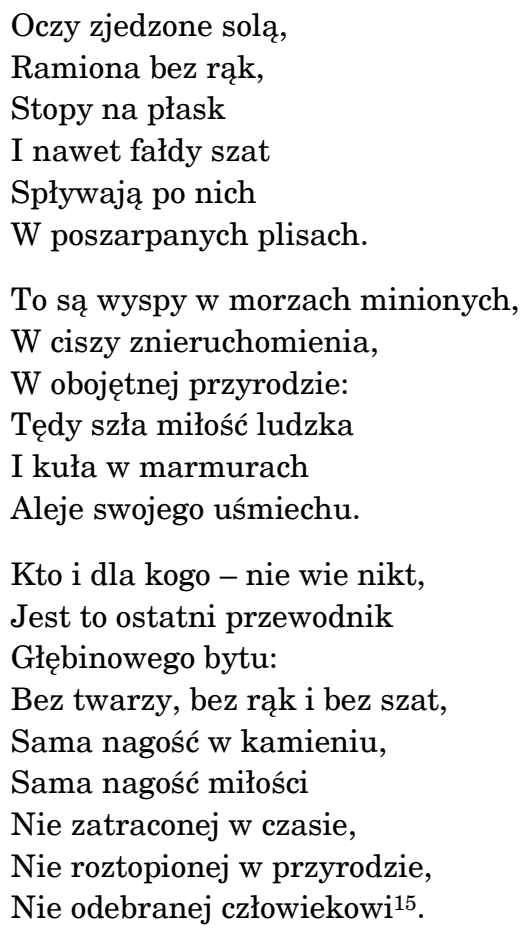

Aleja $w$ głębi czasu (z tomu Sen mara, 1969) Kazimierza Wierzyńskiego to utwór poetycki, którego Serres z całą pewnością nie mógł zamieścić w Statues jako przykładu działania posągów, o których wspomina. Przekonanie, że „Posągi stoją w głębi czasu”, oznacza, że są elementem spoza linearności historii, a jednocześnie są punktem, który organizuje jej chaos. Czas, którego nośnikiem są posągi, ma charakter płynny, twarze są „obmyte z rysów”, pozbawione indywidualności co nie pozwala rozpoznać ich pojedynczych historii, trwają jednakże trwaniem, które Serres dostrzegł w niezmienności skały - przyczynie wysiłku Syzyfa. Są „wyspami” trwania pośród tego, co przeszłe, a zatem umożliwiają myślenie ahistoryczne, a jednocześnie ich materialność nosi na sobie znaki uhistorycznienia. Dla Wierzyńskiego, podobnie jak dla Serresa, status posągu ma charakter metonimiczny - jest tym, co w dotkniętej czasem materii pozwala dostrzec zmarłe ciało, nie pozwala mu odejść i służy za zwornik pamięci, umożliwiającej ocalenie pośród upływu historii. To właśnie ta uhistoryczniona materia, nosząca na sobie ślady zniszczenia, domaga się szczególnego zainteresowania i troski. Zniszczone, pozbawione twarzy, okaleczone „cieleśnie” monumenty są przeciwień-

15 K. Wierzyński, Poezja, wybór i posłowie M. Sprusiński, Kraków 1981, s. 583. 
stwem doskonałych figur rzeźbiarskich, z których można byłoby bezpośrednio wyczytać historię ich pochodzenia. Ale właśnie z powodu tej nieczytelności i braku jednostkowości „posągi w głębi czasu” domagają się innego rodzaju zainteresowania i poznania, opartego na trosce o to, co śladowe, rozbite i zniszczone. Doświadczenie historii jest więc doświadczeniem jej działania na materię, która niszczeje, lecz przez to staje się przedmiotem troski. Z tej perspektywy monumentalna forma rzeźbiarska nie jest możliwa, a historyk byłby tu raczej badaczem materialnych ułomków, które pozostają i którym nie może zostać narzucona żadna spójna, precyzyjna forma ${ }^{16}$. Poznanie historii, które proponują tak rzeźby z utworu Wierzyńskiego, jak i wywód Serresa bazuje na załamaniu Heglowskiej jedności idei i formy zmysłowej posągu, wskazując, że to niszczejąca materialność staje się źródłem poznania przez empatyczną wyobraźnię, nie bezpośredni wgląd w ideę.

To, co pozostaje po człowieku, skała Syzyfa, „nagość w kamieniu” Wierzyńskiego, to figury słabości materii, innej monumentalności - jak powiedziałby Gianni Vattimo. Posągi jako pozostałości materii trwają nie poprzez pełnię obecności, aëre perennius, lecz jako ślady pewnej historycznej prawdy, którą Wierzyński zdaje się traktować po Heideggerowsku, czyli nie jako metafizycznie stabilną strukturę, lecz jako wydarzenie, które wydarza się w rozbiciu, śladzie. Forma monumentalna jest formą naznaczoną erozją, a odkładająca się $w$ takiej formie prawda „nie jawi się już - jak wskazuje Vattimo - ze swoimi autorytarnymi cechami metafizycznej oczywistości"17. Erozja posągów u Wierzyńskiego jest oznaką śmiertelności materii, osłabienia jej i trwania wyłącznie w postaci śmierci.

Dla Vattima monument odnosi się do kondycji słowa poetyckiego:

Jeśli stając się monumentem, słowo poetyckie załamuje się, bowiem przygotowuje się do trwania wyłącznie w postaci śmierci, to monumentalność nawiązuje także do pewnego sposoby wydarzania się prawdy, dla którego charakterystyczna jest właśnie dwoistość natury, wyrażona jednoczesnym odsłanianiem się i zasłanianiem. Do owej dwoistości odwołuje się również samo określenie dzieła sztuki jako miejsca odkładania się prawdy, do którego dochodzi właśnie przez spór świata z ziemią. Oznacza to, że w dziele sztuki obecne jest wydarzanie się

16 Tak o historyku mówił Lukian, porównując go do rzeźbiarza. Zadaniem obu jest praca z nieukształtowaną materią, której muszą nadać formę, by stała się czytelna i precyzyjna. Monumentalna forma rzeźby określała więc oświeceniowy model historycznego poznania, w ramach którego to, co nieciągłe, fragmentaryczne, musiało zostać podporządkowane formie całości, lub wykluczone z niej jako niejasne, nieczytelne - zob. M. Aske, Keats and Hellenism: An Essay, Cambridge 1985, s. 85.

17 G. Vattimo, Rozbicie słowa poetyckiego, [w:] tegoż, Koniec nowoczesności, przeł. M. Surma-Gawłowska, wstęp A. Zawadzki, Kraków 2006, s. 68. 
prawdy właśnie dlatego, że odsłanianie się (świat) zachowuje w nim pamięć o zasłanianiu się, z którego się wywodzi (ziemia) ${ }^{18}$.

Powiązana z monumentalnością, rozbita struktura języka poetyckiego ma kondycję dwoistą, którą w wierszu Wierzyńskiego oddaje paradoksalna wizja posąów trwających dzięki swojej słabości. To posągi, które istnieją poprzez odsłanianie się i zasłanianie, jak „zasłonięte” zdają się twarze pozbawione rysów, odarte przez czas z ludzkiego artyzmu i wskutek upływu historii coraz bardziej upodabniające się, w ruchu rujnowania, do nieczytelnej materii, z której się wywodzą. Posąg jest tu więc figurą takiego poznania, które - idąc ze Serresem - opiera się na uwolnieniu od tyranii przejrzystości i dostępności źródeł oraz dowartościowaniu tego, co nie daje się do końca rozpoznać i odczytać, nie jest metafizycznie stabilną strukturą, ale słabością, wydarzeniem, które zaburza linearność historii i determinujące ją pojęcia przeszłości, teraźniejszości i przyszłości.

\section{Posąg w przestrzeni}

Działanie posągu w dyskursie Serresa to działanie dziwnego atraktora, który zaciera kontury granic pomiędzy porządkami historii, a także przestrzeni, w których się ona wydarza. Dlatego - jak wskazuje Asad - „dynamiczny posąg prowadzi do epistemiczno-krytycznego pytania o przestrzeń"19. Właściwa posągowi statyczność, niezmienność i przestrzenne umocowanie, w perspektywie dziwnego atraktora i uruchomionej przez Serresa teorii chaosu („chaos może być określony jako zmienność, w której zaburzenia zapobiegają pojawianiu się miejsca. Chaos nie dostarcza żadnych punktów odniesienia" [S 191]), zostają załamane, bo w chaosie, który nigdy nie odpowiada na pytanie „gdzie?” [S 192], nie można wydzielić opozycyjnych sfer „tutejszości” i „tamtejszości”. Kluczowe dla Serresa pytanie o miejsce pojawia się wraz z rzeźbą, posągiem, który ulokowany jest $\mathrm{w}$ pojedynczym miejscu $\mathrm{w}$ przestrzeni i tę przestrzeń zaznacza, a jednocześnie ta przestrzeń staje się miejscem właśnie dzięki rzeźbiarskiemu naznaczeniu: „Trup ustanawia kamień, a kamień miejsce. Tu spoczywa - znaczy, że w tym miejscu jest ktoś pochowany, ale zarazem znaczy to: dzięki temu komuś pojawia się to miejsce" [S 61] ${ }^{20}$.

18 Tamże, s. 67.

19 Tamże, s. 124.

${ }^{20} \mathrm{~W}$ tym kontekście można byłoby także przywołać niektóre wiersze Tadeusza Różewicza (np. utwór Pomniki z tomu Rozmowa z księciem, 1960), które są antypomnikami, eksponują dwuznaczność samego pojęcia pomnika. Te właściwości, bez odniesień do Serresa, ale w kontekście wspomnianego przeze mnie Vattimowskiego monumentu, omawia 
Rzeźba ustanawia tutejszość miejsca; wprowadza swoistą organizację przestrzeni, a jednocześnie sama jest przez to miejsce determinowana. Statyczność posągu została przez Serresa zamieniona na formułę dynamiczną, sytuującą rzeźbę w polu otwarcia na przestrzeń. O takim otwarciu pisze on:

W bryle kamienia, drewna, marmuru, granitu [...] rzeźbiarz drąży studzienkę. [...] Rytuał otwarcia ust [...]. Pisanie, jak rzeźbienie i mumifikacja, kultywują ceremonię Otwarcia Ust, lub ją poprzedzają. [...] Kiedy usta otwierają się w bryle, nie wiesz, co się wydarzy. [S 88-89]

We fragmencie tym rzeźba odsłania swój kolejny wymiar: jest figurą otwarcia na to, co nieprzewidywalne, niezorganizowane - na przestrzeń, która dzięki temu otwarciu staje się znacząca, staje się miejscem, choć nie jest to znaczenie ustabilizowane, bowiem sama przestrzeń wnika do posągu, przekształca go i dynamizuje ${ }^{21}$. Zatem, obok czasowości, to szczególnie rozumienie rzeźbiarskiej przestrzeni staje się przyczyną do potraktowania posągu jako figury, która ma pomóc w przeformułowaniu kluczowych kategorii zachodniej epistemologii.

\section{Archeologia pewnego wykluczenia}

Autor Statues, w którego filozoficznej interpretacji pobrzmiewają Heideggerowskie rozpoznania o relacyjnej strukturze rzeźby, uczynił ją centralną figurą nowego modelu wiedzy i poznania. Ta nowa wiedza bu-

Hanna Marciniak - zob. „Nasze pomniki sa dwuznaczne...”. O epitafiach Tadeusza Różewicza, „Teksty Drugie” 2007, 3, s. 22-41.

${ }^{21}$ Serres nawiązuje, choć nie bezpośrednio, do Heideggerowskiego rozumienia zależności rzeźby od przestrzeni. W szkicu Sztuka i przestrzeń rzeźba posłużyła Heideggerowi do rozpoznania esencji dzieła sztuki, którą jest „ujmowanie prawdy”, rozumiane jako dynamiczne współdzielenie, współpraca, towarzyszenie w prawdzie. „Rzeźba byłaby ucieleśnieniem miejsc (Verkorperung von Orten), które otwierając okolicą i przechowując ją, utrzymywałyby skupionym wokół siebie to co wolne, które udziela przebywania danym rzeczom a człowiekowi zamieszkiwania pośród rzeczy" - M. Heidegger, Sztuka i przestrzeń, przeł. C. Woźniak, „Principia” 1991, 3, s. 127. Tak rozumiana rzeźba nie stanowi zawłaszczania przestrzeni, jest raczej nieustannym wchodzeniem w nią, rozszerzaniem się w przestrzeni. Rzeźbiarska bryła nie znaczy tu oddzielania przestrzeni w opozycyjnej logice wnętrza i zewnętrza, ale staje się figurą przynależności do świata, poprzez bycie „pomiędzy”, w stanie otwarcia na przestrzeń, która ją przenika i jednocześnie ingerowania w tę przestrzeń swoją materialnością. To rzeźba, jako ucieleśnienie relacji, przekracza swoją materialność i przestrzenność, jednocześnie nie konfrontując się z nią, nie podbijając jej. Staje się nieodłączna od przestrzeni zmieniając ją tak, że przestrzeń rzeźbiarska staje się czymś pomiędzy - nie jest już przestrzenią pustki, ale jednocześnie nie jest w pełni zajęta. Więcej na temat statusu rzeźby w refleksji Heideggera zob. A. Mitchell, Heidegger Among the Sculptors: Body, Space and the Art of Dwelling, Stanford 2010. 
dowana jest poprzez odkrycie innego, przedjęzykowego źródła, jakim jest posąg, traktowany jako to, co determinuje kategorie poznawcze (czasu i miejsca) oraz poprzedza możliwość postawienia epistemicznych pytań. To posąg jest dla Serresa źródłem doświadczenia i poznania, ponieważ umożliwia relację rzeczy ze słowami i, poprzez swój związek ze śmiercią, stabilizuje związek podmiotu $\mathrm{z}$ przedmiotem. Dla francuskiego filozofa rzeźbiarskie właściwości posągów zostają wpisane w szerszy horyzont dyskusji nad kryzysem nowoczesnej epistemologii, której źródłem jest zapomnienie dynamicznego modelu wiedzy i zastąpienie go stabilnymi opozycjami. Posąg zostaje przez Serresa uznany za szczególne widmo rozumu, niczym martwy, dryfujący w przestrzeni kosmicznej pies Verne'a, bowiem to dzięki niemu możliwe staje się rozpoznanie wykluczeń, zapomnień i przemilczeń, których to, co racjonalne dokonuje, by utrzymać swoją stabilność i spójność. Geneza posągu jest w Statues powrotem tego, co w świecie nauki, faworyzującym „efektywne techniki operacyjne” [S 8], zostaje sprowadzone wyłącznie do posągów w muzeach lub cmentarnych pomników [S 6]: do statycznego stanu, opisywanego w dyskursie antropologicznym. W swojej interpretacji posągów Serres znalazł poręczną metaforę, pozwalającą zrekonstruować genezę tych wykluczających praktyk, a także - poprzez włączenie posągów w logikę dyskursu nauk ścisłych (pojęcie „dziwnego atraktora”; elementy teorii chaosu) wskazuje na konieczność przemyślenia źródeł nowoczesnej dominacji statyki i stagnacji nad dynamicznie rozumianym posągiem.

Cały zbiór krótkich esejów Serresa oparty jest na fundamentalnym zniesieniu granicy pomiędzy myśleniem totemicznym, zakorzenionym $\mathrm{w}$ religii, a nauką. Posąg staje się figurą naruszenia tej granicy, przez co umożliwia przezwyciężenie naukowej alienacji, opartej na wyraźnych podziałach, uprzywilejowaniu dyskursu wiedzy ponad myśleniem religijnym czy magicznym ${ }^{22}$. Stąd też wiele, zapewne dyskusyjnych obiektów, które Serres uznaje za posągi, a które stają się nimi dopiero dzięki przekroczeniu binarnej logiki, nakazującej rozdział pomiędzy tym, co jest dziełem sztuki o proweniencji religijnej, a naukowym wynalazkiem. Niewątpliwie celem Serresa jest próba dotarcia do źródeł wiedzy, jednak wybierając posąg za figurę tego źródła, francuski filozof wskazuje, że jest ono od początku tyleż stabilne naukowo, co wypełnione wiarą, czy myśle-

22 Dzięki temu cały pomysł Serresa można traktować jako ucieleśnienie przemian w samym rozumieniu rzeźby w XX wieku, która: „ledwo dziś zachowuje swój główny atrybut: pozostaje widocznym obiektem, odbijającym procesy psychiczne. Ucieleśnia jednocześnie pewien patos, utrzymujący jej korzenie w magii obiektów totemicznych wieków wcześniejszych, a jednocześnie poszukuje uzasadnienia w surowości modeli naukowych i technicznych innowacji” - J. Burnham, Beyond Modern Sculpture: The Effects of Science and Technology on the Sculpture of this Century, New York 1975, s. 1. 
niem magicznym. W efekcie posąg staje się narzędziem zniesienia podziału na logos i mythos, a jego filozoficzna antropologia, którą proponuje Serres, ujawnia, że logocentryczne uroszczenia rozumu są już u źródeł rozsadzane przez antylogocentryczne uwikłania wiedzy i języka, który ją konstytuuje. W ten sposób filozoficzne ujęcie posągu staje się narzędziem ujawniania sposobów, w jakie logocentryczne myślenie zdeterminowało status samego pojęcia źródła. Za sprawą posągu źródło okazuje się nie stabilnym centrum, początkiem i gwarantem sensu, lecz nieustannie różnicującą się wiązką znaczeń. Poznanie takiego źródła musi więc uwzględniać nieciągłość, dystans i śladowy status przeszłości, a sam posąg, „drugie źródło”, uwolniony zostaje od statyczności i bierności, wpisanych w metafizycznie rozumiany fundament.

\section{BIBLIOGRAFIA}

Aske M., Keats and Hellenism: An Essay, Cambridge 1985.

Assad M.L., Portrait of a Nonlinear Dynamical System: The Discourse of Michel Serres, „SubStance”, Vol. 22, No. 2/3, Issue 71/72: Special Issue: Epistémocritique (1993), <http://www.jstor.org/stable/3685276> (dostęp: 28.05.2017).

Assad M.L., Reading with Michel Serres: An Encounter with Time, New York 1999.

Bilman E., Modern Ekphrasis, Bern 2013.

Burnham J., Beyond Modern Sculpture: The Effects of Science and Technology on the Sculpture of this Century, New York 1975.

Harrison R.P., The Dominion of the Dead, Chicago-London 2003.

Heidegger M., Sztuka i przestrzeń, przeł. C. Woźniak, „Principia” 1991, 3.

Herder G., Sculpture: Some Observations on Shape and Form from Pygmalion's Creative Dream, przeł. J. Gaiger, Chicago, London 2002.

Marciniak H., Nasze pomniki są dwuznaczne...”. O epitafiach Tadeusza Różewicza, „Teksty Drugie” 2007, 3.

Mitchell A., Heidegger Among the Sculptors: Body, Space and the Art of Dwelling, Stanford 2010.

Pismo Święte Starego i Nowego Testamentu w przekładzie z języków oryginalnych [Biblia Tysiaclecia], Poznań 1998 <http://biblia.deon.pl/rozdzial.php?id=259> (dostęp: 25.06.2017).

Serres M., Statues: The Secend Book of Foundations, przeł. R. Burks, London-New Delhi-New York-Sydney 2015.

Serres M., The Apparition of Hermes: Dom Juan, [w:] M. Serres, Hermes: Literature, Science, Philosophy, red. J.V. Harari, D.F. Bell, Baltimore, London 1982.

Vattimo G., Rozbicie słowa poetyckiego, [w:] G. Vattimo, Koniec nowoczesności, przeł. M. Surma-Gawłowska, wstęp A. Zawadzki, Kraków 2006.

Verne J., Wokót księżyca, przeł. L. Duninowska, Warszawa 1970.

Wierzyński K., Poezja, wybór i posłowie M. Sprusiński, Kraków 1981. 